\title{
O Abutre: no entremeio da memória discursiva e do valor-notícia
}

\author{
Bruno de Azevedo Santana Guimarães* \\ UESC \\ Louise Emile Nascimento Marques Pinto** \\ UESC \\ Mauricio Beck $^{* * *}$ \\ UESC \\ Recebido em: 28/o6/2019 \\ Aceito em: 27/11/2019
}

\begin{abstract}
Resumo: O presente artigo objetiva compreender como (ou se) os valores-notícia funcionam na/pela memória discursiva, naquilo que toca a dinâmica mercadológica-capitalista de comercialização da informação. A análise é feita a partir de recortes verbais e sequências imagéticas do filme O Abutre (2014), dirigido por Dan Gilroy. O fato noticiável perpassa pelo crivo da antecipação de audiência e favorece um efeito de moralidade na circulação do discurso jornalístico. Assim, é a partir desse imbricamento teórico que se desenvolve o trabalho, com base naquilo que as linguagens engendram na articulação do "fazer notícia" e a memória de outros dizeres.
\end{abstract}

Palavras-chave: Valor-notícia. Cinema. Análise de Discurso Materialista. Mercadoria.

\begin{abstract}
The present article aims to understand how (or if) news values work in / through discursive memory, in what touches the marketing-capitalist dynamics of commercialization of the information. The analysis is made from verbal clippings and imagetic sequences from The Vulture (2014), directed by Dan Gilroy. The newsworthy fact runs through the sieve of anticipation of audience and favors an effect of morality in the circulation of journalistic discourse. Thus, it is from this theoretical interweaving that we develop the work, based on what languages engender in the articulation of "making news" and the memory of other sayings.

Keywords: News values. Cinema. Materialistic Discourse Analysis. Goods.
\end{abstract}

Resumen: Objetiva comprender como (o si) los valores-notícia de los periódicos funcionan en/ por la memoria discursiva, en aquello que toca la dinámica mercadológica-capitalista de la comercialización de la información. Es analizados recortes verbales y secuencias imagéticas de la película "O Abutre" (2014), dirigida por Dan Gilroy. El facto noticiable pasa por el cribo de la anticipación de la audiencia y favorece un efecto de moralidad en la circulación del discurso jornalístico. A partir de esa superposición teórica que desarrollamos nuestro trabajo, basado en aquello que las lenguajes generan en la articulación del "hacer notícia" y la memoria de otros decires.

Palabras clave: Valor-noticia. Cine. Análisis del Discurso Materialista. Mercancía. 
"A maneira mais clara de ilustrar esta realidade, Lou, que captura o verdadeiro espírito de quem somos, é pensar no nosso noticiário como sendo uma mulher aos berros correndo pela rua com a garganta cortada."

(Nightcrawler. O Abutre, 2014)

“...e se a palavra realidade não significa outra coisa senão o conjunto das conexões pelas quais nossa vida é amalgamada e suportada, então é com certeza verdadeiro que precisa haver regiões ou camadas da realidade muito diversas."

(Heisenberg. A Ordenação da Realidade, 2009)

\section{Introdução}

As instituições de comunicação, principalmente a mídia televisiva, permeiam o cotidiano dos sujeitos citadinos através da exibição e do consumo de programas de entretenimento, de filmes e de telejornais. Sobre estes últimos, existe todo um labor interno das redações de notícias que são, muitas vezes, desconhecidas do grande público. A produção e veiculação da notícia possuem um trâmite complexo e que, às vezes, necessita de um “incremento" externo à equipe de profissionais de televisão.

Os chamados freelances percorrem a cidade em busca de material videográfico para vender às emissoras de TV, e estas exibem com exclusividade no horário nobre do seu telejornal. Geralmente, estes materiais são registros audiovisuais da tragédia, da dor e do sangue alheio. É nesse cenário de busca pela notícia sensacionalista que se desenvolve a trama do filme O Abutre (2014), dirigido por Dan Gilroy.

No presente artigo, por conseguinte, serão analisados recortes verbais e sequências de imagens da obra fílmica para a realização de gestos de análise com vistas a compreendermos como o labor de determinadas práticas jornalísticas se valem de situações trágicas e fazem, assim, questionar a ética jornalística e o conceito de valor notícia.

Para tanto, como base teórica, serão mobilizados conceitos da Teoria da Comunicação (PENA, 20o8; TRAQUINA, 2008) em confluência com a Análise do Discurso Materialista (AD) (PÊCHEUX, 2015, 2014). No primeiro momento, discutiremos 
acerca de valores-notícias, ou seja, critérios utilizados pelas redações de jornais para veicular ou não uma notícia. O aspecto de memória e suíte jornalística aparecem em seguida, bem como as considerações sobre discurso ficcional (PEREIRA, 2012; SOUZA, 2015). Por fim, serão analisados recortes da obra fílmica à luz das teorizações sobre o discurso do jornalismo (MARIANI, 1989) e AD (PÊCHEUX, 2014; ORLANDI, 2016).

Analisar como o filme representa o labor jornalístico é pensar, também, como o imaginário social se inscreve na materialidade discursiva da notícia bem como a prática jornalística que faz parte do "horário nobre" da televisão e da disputa pela audiência.

\section{Valores-notícia: Com sangue?}

Para que possamos discorrer a respeito das formulações midiáticas, ou mesmo os meios de organização da comunicação televisiva, é preciso antes retornar a alguns conceitos de Louis Althusser, quando o autor conceitua Ideologia. Em uma vertente materialista, Althusser, em uma releitura a Marx, lança a tese de que a Ideologia funciona por meio de práticas regulares. É na manutenção da reprodução, ou da transformação, das relações de produção que tomamos como evidência, como um sempre-já-lá, ou mesmo como se não fosse de outro modo, os sentidos que permeiam e ordenam o social e o institucional. Com efeito, os aparelhos repressivos e ideológico(s), funcionam de forma engendrada e simultânea para garantir a manutenção da reprodução das relações de produção (ALTHUSSER, 2008, p. 264-268).

As instituições de comunicação podem ser compreendidas enquanto Aparelhos Ideológicos de Estado (ALTHUSSER, 1987) que se realizam pelas práticas que exercem no social. Althusser afirma que essas práticas institucionais "são regulamentadas por rituais nos quais elas se inscrevem, no âmago da existência material de um aparelho ideológico" (ALTHUSSER, 1987, p. 282). Uma escola é reconhecida pela prática educacional, um hospital, pelo tratamento de saúde, uma igreja, pelo hábito da oração e, assim, sucessivamente. Naquilo que toca não só a esfera das instituições, mas também aos sujeitos, considera-se que 
a existência das ideias da sua crença é material, no sentido de que suas ideias são seus atos materiais inseridos em práticas materiais, reguladas por rituais materiais que, por sua vez, são definidos pelo aparelho ideológico material do qual dependem as ideias desse sujeito (ALTHUSSER, 1987, p. 282).

Remontando a Althusser, Mariani (1998, p.71) explica que há um processo de "todo mundo sabe" em relação às práticas de cada instituição, por isso, saber de tais práticas é adentrar no campo da evidência:

Esse processo histórico de naturalização das instituições funciona no sentido de torná-las 'evidentes’, legítimas e necessárias; da mesma forma, ao longo do tempo, passa-se a considerar como naturais os discursos que nelas 'emanam', bem como os comportamentos a elas associados (MARIANI, 1998, p.71).

Entretanto, as empresas de comunicação produzem práticas que estão inscritas no modo de produção capitalista, pois, como instituições, devem obedecer ao processo "natural" do lucro através da "venda" da notícia, seja ela impressa, televisiva, radiofônica ou digital. Ou seja, concorre - tal como todos os AIE's - para o mesmo resultado: "a reprodução das relações de produção, isto é, das relações de exploração capitalistas” (ALTHUSSER, 2008, p. 272). Em outras palavras, estar no mercado da informação, significa concorrer ao espaço da melhor audiência, das maiores tiragens e dos expressivos acessos. Logo, a notícia "fresca", produto a ser ofertado, torna-se um "artigo de luxo", disputado pelos conglomerados midiáticos a fim de obter uma maior audiência e o maior lucro através dos anunciantes. E, assim, na dinâmica da manutenção da exploração capitalista, empanturrar "todos os 'cidadãos' com doses cotidianas de nacionalismo, chauvinismo, liberalismo, moralismo etc" (ALTHUSSER, 2008, p. 272).

O que está em jogo na competitividade entre as instituições é o furo de notícia. Nas redações, o factual - o fato mais inesperado como acidentes, assassinatos, descobertas científicas, entrevistas exclusivas, ganha o efeito de notícia para ser exibido (PENA, 2008) e mantém as emissoras de televisão em constante alerta, contando, inclusive, com pessoas dispostas a vender tais informações. A redação de jornal, através dos profissionais que trabalham na produção e apuração de acontecimentos, já não comporta mais a função de "descobrir" a notícia; é necessária a oferta de "profissionais" que não fazem parte do quadro da instituição, para que tais furos de notícias sejam veiculados com exclusividade. Os freelancers, isto é, profissionais autônomos (e precarizados) que vendem materiais audiovisuais às TVs e jornais impressos, fazem 
parte cada vez mais frequente do cotidiano das emissoras por não estarem presos a uma cabine, entre quatro paredes, um computador e um telefone. Eles estão nas ruas, nas esquinas, nas vielas da cidade à procura de materiais que possam gerar notícia, ou, pelo menos, ganhar tal efeito. Há de se observar que o trabalho de freelancer só será pago caso este encontre e produza audiovisuais com valor-notícia. Com isso, desonera-se a folha de pagamento da empresa. Parcela dos trabalhadores não são mais pagos pelas horas de trabalho, mas pelo produto, o furo jornalístico (mercadoria escassa), que têm a ofertar à empresa televisiva.

Esse é o cenário da ficção estadunidense de $O$ Abutre [título original: Nightcrawler], dirigido por Dan Gilroy e lançado no ano de 2014. Trata-se de um filme enquadrado no gênero policial/drama, de acordo com o mercado cinematográfico, e o enredo gira em torno da personagem Louis Bloom, interpretado por Jake Gyllenhaal, que não consegue se manter em um emprego formal e encontra espaço na informalidade e na precariedade da venda de material videográfico sobre crimes e assassinatos, para grandes emissoras de jornais. Seu envolvimento no mundo jornalístico não é atravessado por formação acadêmica, nem mesmo técnica. Com o rádio sintonizado em um canal policial e uma filmadora para capturar o horror de drásticos crimes, Bloom se identifica com esses cenários, o melhor ângulo, na melhor luz. Há algo, na apresentação da personagem - suas olheiras, roupas em tons escuros e um rosto marcadamente magro, que delineiam os ossos - bem como nas cores escuras do cenário, quase sempre com pouca luz, que denuncia sua relação com aquilo que, corriqueiramente, evitamos enunciar, a morte. Uma vez que,

\footnotetext{
A nós nos é vetada a experiência direta da morte. Essa assertiva obrigou as diversas culturas, cada qual a seu turno a efetivarem suas relações com esse real inexorável pela via do simbólico. O estilo particular dessa simbolização define a especificidade dos rituais de cada povo, de cada cultura. O real da morte, por isso, nunca se apresenta por completo, será sempre definido em seu entorno, pela linguagem, signatária original da cultura (PEREIRA, 2012, p. 82-83).
}

Em O Abutre, o cenário soturno ou de lusco-fusco se contrapõe ao imaginário da ensolarada Califórnia, majoritariamente retratado nos filmes hollywoodianos. É outra a memória cinematográfica atualizada no filme: a do lado B de Los Angeles, mundo das subcelebridades notívagas, de disputas acirradas e de intrigas movidas pelo desejo de fama e de sucesso. Sentidos e cenários que remetem ao cinema noir e suas releituras 
como Chinatown (1974) de Polanski, ou ao ordinário dos bastidores do mundo do espetáculo, como em Barton Fink: delírios de Hollywood (1991), dos irmãos Coen.

Imersos no enredo da história, que funciona como um discurso cinematográfico sobre os bastidores das práticas jornalísticas, nos questionamos sobre os seguintes pontos: afinal, o que pode e deve ser notícia? Como um acontecimento ganha tal efeito? Todo acontecimento é notícia? E antes disso: o que é um acontecimento? Tais questionamentos são comuns àqueles que não fazem parte do cotidiano de uma redação de jornal e, talvez por isso, Louis Bloom, ao levar seu primeiro material videográfico à emissora de televisão, questiona Nina Romina (Rene Russo), chefe de reportagem do telejornal noturno, sobre que tipo de imagens ele deveria obter para posteriormente negociá-las. Vale já considerar a linha editorial do jornal que aceita e compra as imagens produzidas por Bloom. O material das notícias segue um imperativo de quantificação da audiência, uma dinâmica que disputa a atenção e a fidelidade do espectador, que ordena o tempo, o momento oportuno para vincular a "informação", já com os devidos cortes e montagens. A especificidade do programa televisivo é, segundo nossa leitura, o exagero de fatos e informações, a notícia-sensação. No Brasil, chamamos imprensa marrom (yellow press nos EUA) quando o que é veiculado significa, e captura a atenção curiosa de espectadores, de modo sensacionalista e sem escrúpulos. Podemos interpretar que, neste caso, o valor notícia é sobretudo um valor-sensação, em detrimento do valor informativo.

Antes de se tornar um freelancer, Louis se aventura pelo mundo de pequenos roubos em áreas públicas, ou de objetos privados. É quase por acaso que ele descobre o universo "cinematográfico amador" da captura de imagens caóticas, como o estado das vítimas em acidentes, invasão de casas etc. Em suma, ele vai continuar a furtar, só que, agora, serão imagens da desgraça do outro. O que está em jogo na venda dessas imagens é a insensibilidade ${ }^{1}$ em extrair o que houver de mais brutal, com maior nitidez e um cauteloso rigor nos detalhes.

1Esta insensibilidade que não pode falhar - a condição precária do freelancer impede que ele se volte contra o imperativo do valor notícia-sensação? - diverge da ética dos repórteres fotógrafos cariocas documentados no filme "Abaixando a Máquina: ética e dor no fotojornalismo carioca" (2008), de Guilherme Planel e Renato de Paula. Com efeito, segundo os gestos de análise sobre o filme, a "apraxia do fotógrafo recusa a demanda do mercado de clientela voyeur e abre mão da remuneração do empregador. Se a fratura exposta da violência física, objetificada no registro fotográfico, se faz mercadoria corrente na tradição da mídia, a dor psíquica dos sujeitos obstaculiza o rito da livre troca

Revista Investigações, Recife, v. 32, n. 2, p. 396 - 418, Dezembro/2019 


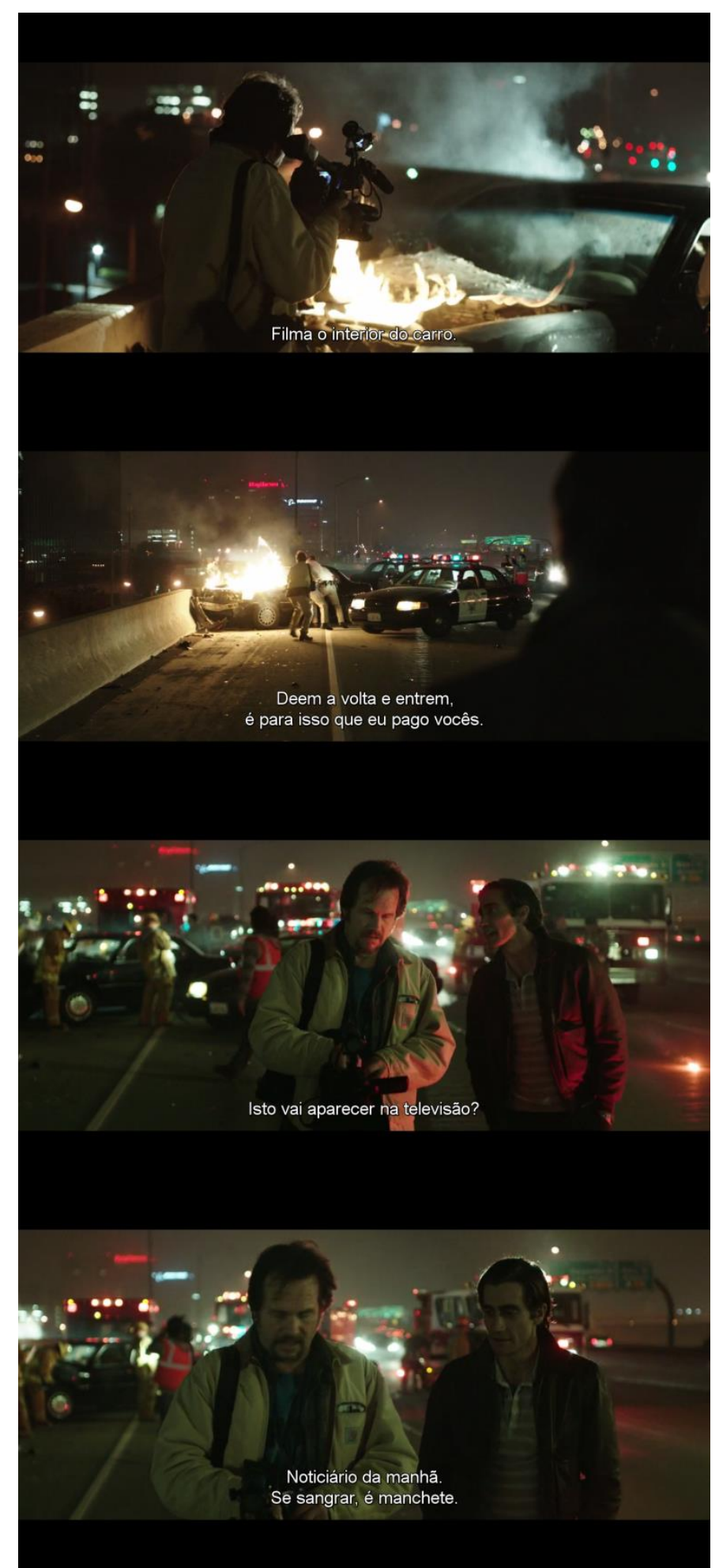

Print Screen do filme O Abutre (2014). Tempo: o7m37s; 07m42s; 08m23s e o8m25s, respectivamente

Os recortes acima mostram o primeiro contato de Louis com o cenário de trabalho de um freelancer, um catador de notícias. Ele está na cena sempre como um

consentida entre as partes. A dimensão da dor incomensurável, muitas vezes, desmonta o dispositivo de captura-circulação-consumo. Temos assim a marca do sujeito que se faz patente pela ausência de suas práticas." (BECK, 2013, p. 110).

Revista Investigações, Recife, v. 32, n. 2, p. 396 - 418, Dezembro/2019 
observador, a câmera cinematográfica enquadra os objetos em plano médio e plano aberto, como se estivéssemos perto demais do fogo, do perigo, ora tomamos o lugar de Bloom como espectador do acidente, ora captamos os movimentos do homem com a câmera. Essa sequência de plano aberto nos ambienta ao espaço, ao jogo de posições entre os objetos e os sujeitos-personagens na obra fílmica. A pergunta seguinte já apresenta o que questionamos anteriormente sobre o que pode ter o efeito de notícia. É uma resposta simples, quanto maior o desastre, maior a relevância do material, e com sangue, ele se torna a "estrela" principal.

O que está posto é uma relação com os afetos, é também a movimentação de um imaginário que permeará os espectadores, numa possibilidade de identificação com o outro na cena jornalística, ou mesmo de quase-identificação, uma resistência ao real traumático, "ainda bem que não foi comigo". Para Dunker; Rodrigues; Senhorini, em leitura a Lacan, "os sentimentos são como afetos socializados, ou melhor, vividos de maneira particularmente compartilhada, notadamente quanto à interpretação das disposições supostas ao Outro" (DUNKER; RODRIGUES; SENHORINI, 2017, p. 10). Portanto, a significação afetiva funciona tanto para a imagem apresentada na ficção jornalística, quanto para a montagem cinematográfica; o que se espera é sempre o melhor ângulo e o mais envolvente enredo.

Seguem outros recortes imagéticos para análise a partir da seguinte questão de análise: como (ou se) o valor-notícia funciona na memória discursiva? 


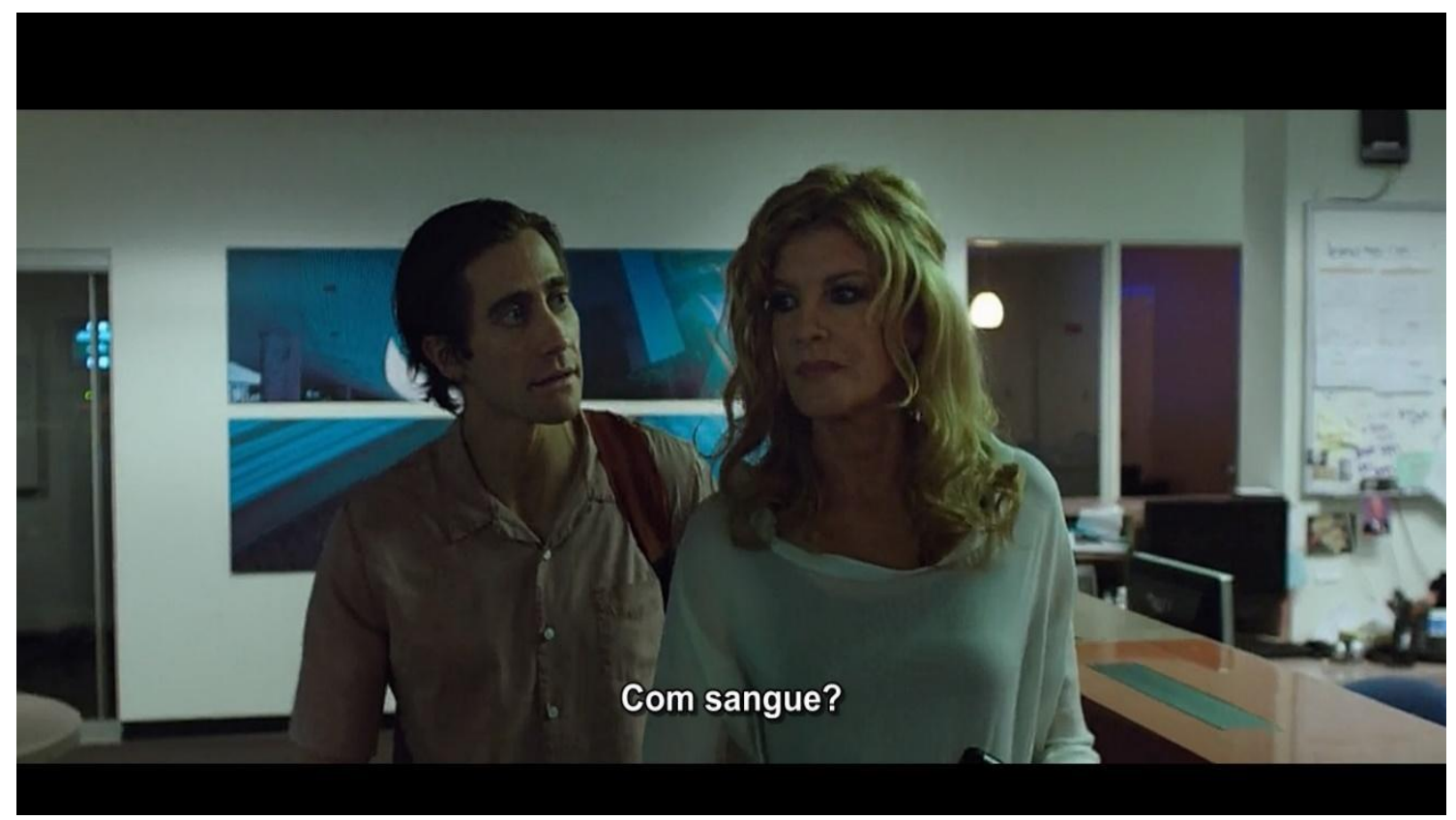

Print Screen do filme O Abutre (2014). Tempo: 20m12s

Assim, o que está posto na dúvida de Bloom é a retomada de uma memória discursiva que estabelece certo padrão a todos os noticiários sensacionalistas que tenham considerável circulação, ou seja, certa imposição implícita na dinâmica do que pode e deve ser noticiável. Há um retorno não marcado sobre a divulgação de imagens que denunciam acidentes, crimes e afins, o real da morte, como sendo as exposições mais rentáveis, que interferem diretamente na audiência, na lucratividade da instituição. A fala de Nina destaca os critérios de noticiabilidade e veiculação, ou seja, de valores notícias, como será analisada na sequência verbal a seguir:

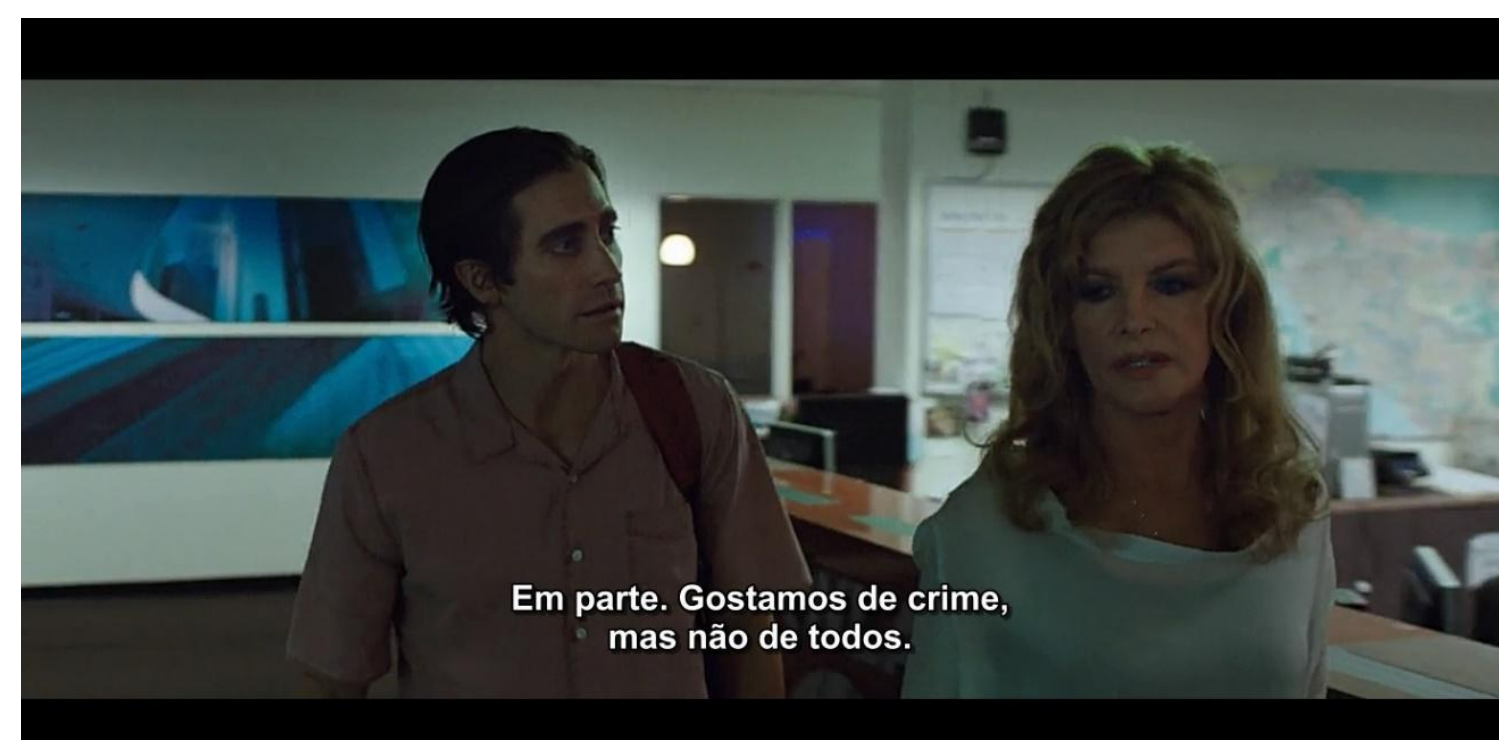

Revista Investigações, Recife, v. 32, n. 2, p. 396 - 418, Dezembro/2019 
Print Screen do filme O Abutre (2014). Tempo: 20m18s

Louis: Com sangue?

Nina: Em parte. Gostamos de crimes, mas não de todos. O roubo de carro em Campton, por exemplo, não é notícia, certo? Nossos telespectadores se interessam mais por crimes urbanos que ocorrem nos subúrbios. As vítimas são bem de vida, brancos e feridos pelos pobres ou por uma minoria.

Louis: Crimes?

Nina: Não. Acidentes também. De carro, de ônibus, trem, avião, incêndio.

Louis: Mas com sangue?

Nina: Com imagens fortes. O melhor conselho, Lou...é captar o espírito do que levamos ao ar. Pense em nós como uma mulher que grita correndo pela rua com a garganta cortada.

Louis: Entendi.

Para analisarmos o diálogo acima, precisamos entender primeiro que existe no labor jornalístico critérios de noticiabilidade que, como supracitado, são chamados de "valores-notícia”, isto é, acontecimentos que possuem um "grau de noticiabilidade" (PENA, 2008, p. 71) e que explicam a "capacidade que os fatos têm de virar ou não notícia” (p.71). De outro modo, Nelson Traquina (2008, p. 63) informa que a noticiabilidade pode ser definida como o "conjunto de critérios e operações que fornecem a aptidão de merecer um tratamento jornalístico, isto é, possuir valor como notícia”. Dito isto, entendemos que os critérios de noticiabilidade são ideológicos, ou seja, para um fato virar ou não notícia, depende do valor que o jornalista/instituição dará, ou não, ao acontecimento. Além de uma prática ideológica, a notícia, como discurso, funciona como uma prática política, conforme explica Mariani (1998):

O discurso jornalístico desempenha um papel importante na produção/circulação de consensos de sentido. Isto perpassa os jornais como um todo - apesar das diferenças existentes em termos de posicionamento político de cada jornal - e organiza uma direção na produção dos sentidos políticos (MARIANI, 1998, p.66).

Desta forma, a autora explica que a produção e a divulgação do discurso jornalístico tornam-se, também, um ato de tomada de posição política. Mesmo que cada instituição possua posições ideológicas antagônicas, morte, crimes, acidentes e fatos que envolvam sangue, geralmente, são tratados como passíveis a ganhar um efeito de notícia.

No excerto "gostamos de crime, mas não de todos", como parte da resposta de Nina a Louis, entendemos que, embora boa parte dos crimes se tornem notícias, nem Revista Investigações, Recife, v. 32, n. 2, p. 396 - 418, Dezembro/2019 
todos serão noticiados: "O roubo de carro em Campton, por exemplo, não é notícia, certo?”, explica. Outro ponto interessante do diálogo que também está ligado ao processo de atribuir valor a um acontecimento para que este ganhe um efeito de notícia, diz respeito à antecipação que os jornais fazem daquilo que o público irá se interessar, ou não: "Nossos telespectadores se interessam mais por crimes urbanos que ocorrem nos subúrbios"”. E, sobre o interesse do público, entendemos que para que haja audiência, é preciso que os espectadores se inscrevam na Formação Discursiva (FD) da instituição jornalística. Pêcheux (2014 [1975], p.161), explica que por haver similaridades em relação ao discurso, a FD torna-se um espaço onde se constitui a ilusão necessária de uma “intersubjetividade falante" pela qual cada um sabe de antemão o que o "outro" vai pensar e dizer..., e com razão, já que o discurso de cada um reproduz o discurso do outro (uma vez que, como dizíamos - cada um é espelho dos outros). Se interessar, ou não: "Nossos telespectadores se interessam mais por crimes urbanos que ocorrem nos subúrbios".

Articulada e em funcionamento com as formações discursivas estão as formações imaginárias "[...] que designam o lugar que $A$ e $B$ se atribuem cada um a si e ao outro, a imagem que eles se fazem de seu próprio lugar e do lugar do outro." (PÊCHEUX, 2014 [1969], p. 82, grifos do autor). Ou seja, o que a personagem está dizendo é que, para dizer/noticiar X esperando a resposta de interesse do espectador, se faz também a imagem do espectador médio, para a qual é endereçado o discurso jornalístico. Esse jogo todo é sustentado por esse espaço de ilusões da FD. Assim, os jornais sabem, não só pela convergência do discurso entre instituição e público, como também pela audiência e a venda de jornais, quais assuntos são mais “consumidos”. Percebam, entretanto, que esta é uma situação que envolve não só os processos discursivos, como também econômicos, uma vez que, como instituições que estão no processo capitalista de oferta e procura, os jornais se preocupam com os lucros oriundos da divulgação da notícia.

Além disso, outro aspecto interessante na explicação de Nina a Louis sobre o processo de interesse do público, diz respeito ao antagonismo e às diferenças de classes, quando ela explica que "as vítimas são bem de vida, brancas e feridas pelos pobres ou

2 Importante lembrar que nos EUA a distribuição das residências de diferentes classes sociais no espaço urbano é diversa da brasileira. Lá, bairros classe média e classe média alta, muitas vezes, estão situados nos subúrbios. Um correspondente brasileiro possível seria a dos espaços semi privados dos condomínios das classes economicamente mais privilegiadas.

Revista Investigações, Recife, v. 32, n. 2, p. 396 - 418, Dezembro/2019 
por uma minoria”. Parece haver um imaginário que define as coordenadas do script do que é noticiável: a dita classe média alta representa o papel de vítima das classes subalternas e da parcela da população que são/estão reconhecidas como minorias. Quando os fatos confirmam tal script adquirem valor notícia-sensação.

Desta forma, entendemos que, através deste discurso, há um imaginário étnicoeconômico-racial, uma vez que uma classe econômica e uma etnia serão personagemvítima de notícias quando hostilizadas pelas outras, a antagonista. Quem ocuparia o lugar do protagonista neste script? Na maioria dos casos, parece ser o policial3. Conforme as coordenadas deste script-notícia, uma classe e uma etnia, supostamente a do sujeitoespectador médio, ocupa o lugar da vítima. Cabe observar que a imposição de um script, que estabelece correlações fixas entre protagonistas, antagonista e vítimas e dadas classes e etnias, na apreciação do valor notícia-sensação de registros factuais do cotidiano urbano, faz borrar a cisão de nosso senso comum entre a dita realidade e a ficção.

Para encerrar o diálogo com Louis e explicar quais são os critérios de noticiabilidade e os processos pelos quais a instituição divulga as notícias, Nina orienta que a notícia possua o critério não só de exclusividade, como também de imprevisibilidade. Afinal, como diz o ditado criado por Charles Anderson Dana (18191879) nas redações de jornal: "Se um cão mordeu um homem, isso não é notícia. Mas se um homem morder um cão, isso é notícia!"”.

3 "Se podemos dizer que um personagem ficcional tem dominado a cultura popular atual, esse personagem é o policial." (BEY, 2003, p.64).

4A propósito deste ditado, cabe comentar que, na coletânea Histórias Macabras (1979), selecionadas pelo cineasta Alfred Hitchcock, consta um conto cujo título é justamente Homem morde cachorro (1960). De autoria de Donald Honig, o enredo gira em torno do trabalho jornalístico em uma pequena cidade norte-americana. O narrador, em primeira pessoa, é contratado pelo editor do jornal da cidade para ocupar o lugar do editor associado que desaparecera. Com o transcorrer das semanas, o jovem contratado começa a ficar ciente da dificuldade que é preencher o periódico de notícias em uma pacata cidade, onde quase nada acontece. Até que certo dia, a crise se instaura. Não havia absolutamente acontecimentos para preencher as páginas do jornal. Para resolver o impasse, o editor-chefe pega uma antiga espingarda e a dupla de jornalistas entra no carro e sai da cidade. Em uma velha estrada avistam um homem andando. Após trocar breves palavras de saudação, o editor-chefe ergue e dispara o rifle contra o homem. O editor associado, tomado de surpresa e espanto, se dá conta que seu chefe acabara de produzir propositalmente um acontecimento para preencher as páginas de seu jornal. O enredo continua com outras produções de acontecimentos sangrentos e com a suspeita angustiada, da parte do editor associado, de que o desaparecimento do seu antecessor também fora motivado para vender jornais. Por fim, a espada volta-se contra o espadachim, e o editor associado decide matar seu chefe para noticiar sua misteriosa morte, e herdar o ofício. O que o hiperbólico enredo deste conto macabro torna patente é que, em se tratando de imprensa marrom, o valor notícia-sensação impõe-se ao ofício jornalístico de tal modo que, se não há nada a noticiar, o jornalista pode ser tentado a produzir

Revista Investigações, Recife, v. 32, n. 2, p. 396 - 418, Dezembro/2019 


\title{
Memória: a suíte jornalística como efeito de atualidade
}

À medida que Louis Bloom ganha experiência e progride no negócio, ele começa a gravar todas as reportagens que são exibidas com imagens vendidas por ele. Cada matéria ganha um título que remete ao fato ocorrido. O que se impõe nessa forma de organizar é o seu gesto de leitura sobre o fato e o que pode vir a ser notícia, a formulação de um arquivo, que também se apresenta como uma forma de delinear a memória. Nessa linha,

[...] há, entretanto fortes razões para se pensar que os conflitos explícitos remetem em surdina clivagens subterrâneas entre maneiras diferentes, ou mesmo contraditórias, de ler o arquivo (entendido no sentido amplo de 'campo de documentos pertinentes e disponíveis sobre uma questão') (PÊCHEUX, 2014, p. 59, grifos do autor).

Antes que avancemos, vale marcar o conceito de memória no qual nos baseamos: este não é tem um sentido psicologista, “da 'memória individual', mas é definido por sentidos entrecruzados da memória mítica, da memória social inscrita em práticas, e da memória construída do historiador" (PÊCHEUX, 2015, p. 44). Nessa linha,

\begin{abstract}
a memória discursiva seria aquilo que, face a um texto que surge como acontecimento a ler, vem restabelecer os "implícitos" (quer dizer, mais tecnicamente, os pré-construídos, elementos citados e relatados, discursostransversos etc) de que sua leitura necessita: a condição do legível em relação ao próprio legível (PÊCHEUX, 2015, p. 46).
\end{abstract}

Pêcheux retoma Achard ao abordar que esses implícitos não são bem definidos, estariam funcionando por meio da contradição, pois, estão implícitos. A saída é compreendermos como um “efeito de série pelo qual uma 'regularização’[...] se iniciaria, e seria nessa própria regularização que residiriam os implícitos, sob a forma de remissões, de retomadas e de efeitos de paráfrase" (PÊCHEUX, 2015, p. 46). É esse entrecruzamento de retomadas, repetições de discursos outros inscritos no espaço da memória e atualizados nas condições de sua produção que ponderamos sobre o efeito de notícia e trazemos o recorte abaixo.

inescrupulosamente fatos para vender jornal. $O$ trabalhador precarizado de $O$ Abutre chega a um limiar muito próximo deste, conforme analisaremos mais adiante.

Revista Investigações, Recife, v. 32, n. 2, p. 396 - 418, Dezembro/2019 


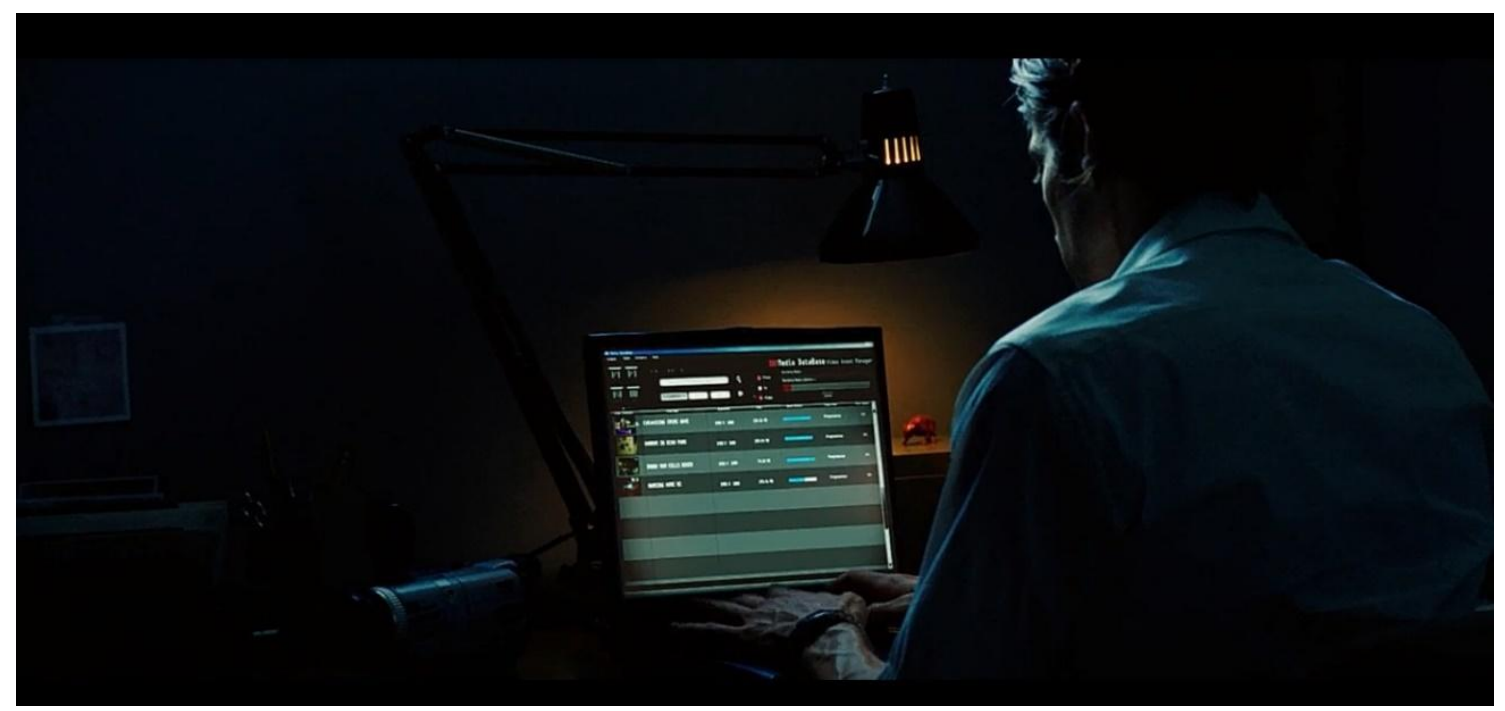

Print Screen do filme O Abutre (2014). Tempo: 37m32s

A notícia, como efeito de um acontecimento, faz parte da prática jornalística e é comum nas redações de jornais que alguns assuntos ganhem novas sequências, isto é, novos desdobramentos. A reportagem que explora os desdobramentos de uma matéria anterior é chamada de "suíte", isto é, uma notícia que apresenta alguma "novidade" a um assunto já divulgado. Assim, toma-se como exemplo a reportagem da morte de uma personalidade famosa. A primeira matéria se divulga a morte, quando aconteceu, onde aconteceu, como aconteceu, porque aconteceu... e alguns detalhes ainda superficiais, já que se tratou de uma morte inesperada e com informações ainda muito recente. A produção e a equipe de reportagem do jornal, por sua vez, trabalharão na busca de novas informações, entrevistas, dados e, assim, montar uma nova matéria sobre o mesmo assunto que ganha um efeito de novidade. Desta forma, do ponto de vista discursivo, entendemos que a suíte, ou melhor, a reportagem que atualiza um fato, se vende como (o simulacro de) um novo acontecimento a ler, pois, conforme Pêcheux (2015, p.16) descreve, encontra-se "no ponto de encontro de uma atualidade e uma memória". Dito de outro modo, a reportagem atualiza com informações novas um fato que ganhou o efeito de notícia e mobiliza, também, a memória do ocorrido para a melhor compreensão dos sentidos. Suitar uma matéria é fazer tais mobilizações, relembrar os fatos e atualizálos. Vejamos sobre a suíte a seguir.

Na trama O Abutre, Louis Bloom chega ao local de um crime no exato momento em que os bandidos deixaram uma mansão após matar uma família inteira num bairro 
de classe média alta. Bloom grava toda a cena dos bandidos fugindo do local e que revela não só a identidade dos bandidos, como também a placa do carro utilizado para a fuga. Louis edita a fita que gravou, não comunica a Nina que tem o material gravado para a venda e, consequentemente, valoriza seu produto uma vez que, no mercado, a lei da oferta e da procura tende, geralmente, por valorizar monetariamente o produto escasso ou tido como indisponível. Ao ser questionado sobre o motivo de ter "sumido" e não ter avisado que tinha o material, Bloom responde:

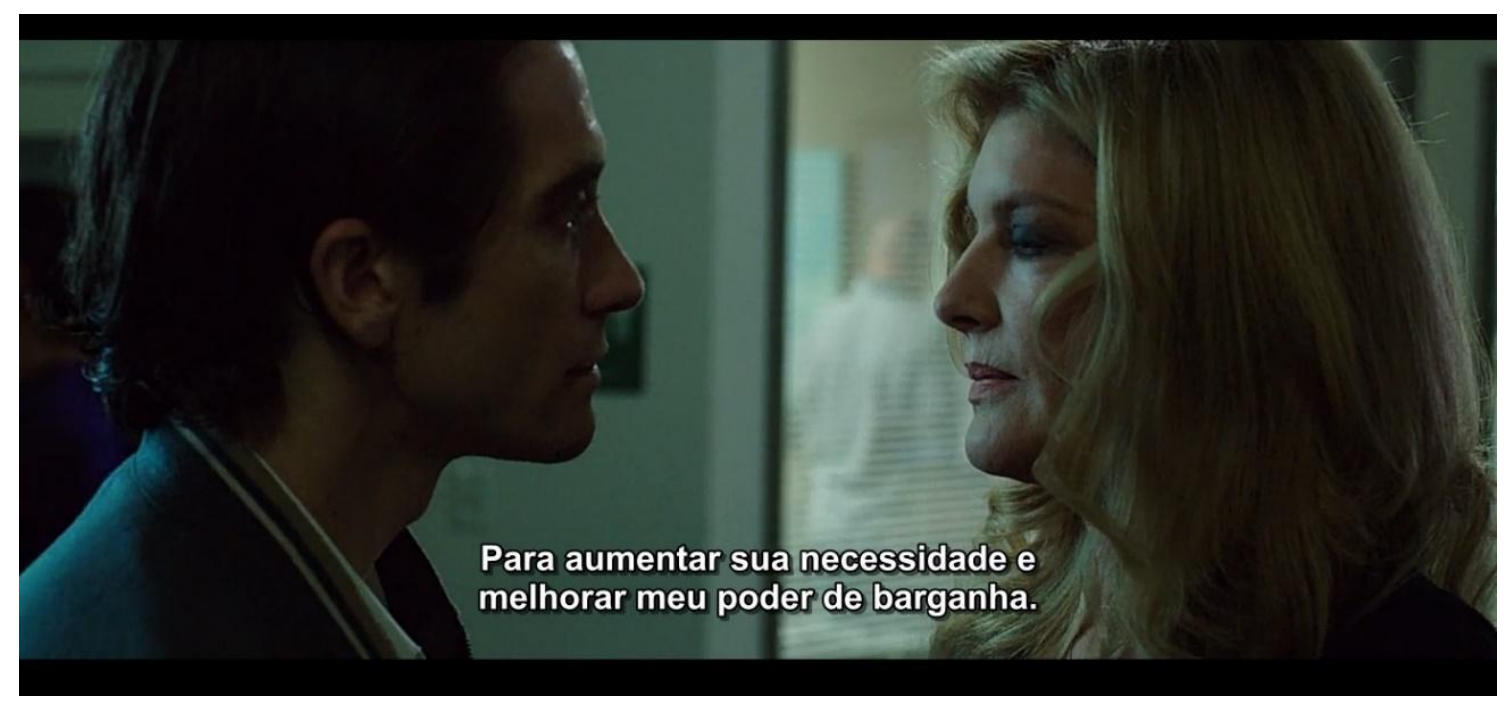

Print Screen do filme O Abutre (2014). Tempo: 1ho8moos

"Para aumentar sua necessidade e melhorar meu poder de barganha". O escopo não é só monetizar as informações que possui e poder vender a um preço maior à TV, mas também colocá-lo em uma posição de 'poder' dentro da estrutura do telejornal, promovendo sua empresa, a Video Production Services, e conhecer os sujeitos que mais têm influência monetária na emissora (diretores e produtores executivos).

Dando continuidade à trama, o assassinato, presenciado e filmado por Bloom, cria uma tensão nos bastidores do telejornal, uma vez que as imagens capturadas pelo "abutre" "ferem" a ética jornalística e criam um efeito de sensacionalismo através das mortes da família. Frank Kruse, editor da emissora, se posiciona contrário à iniciativa de Nina, em relação a mostrar tais imagens no telejornal noturno. "Estamos além dos padrões de transmissão", diz Frank. Contudo, a posição de Nina vence a batalha éticomoral entre ambos e ela exibe todo conteúdo com exclusividade, o que gera um recorde na audiência. Entretanto, o motivo de Bloom ter editado e omitido informações cruciais 
à investigação da polícia que continha as identidades dos assassinos é criar um cenário cilada aos bandidos e ele, ao filmar todo ocorrido, pode lucrar novamente através da exclusividade de seus materiais.

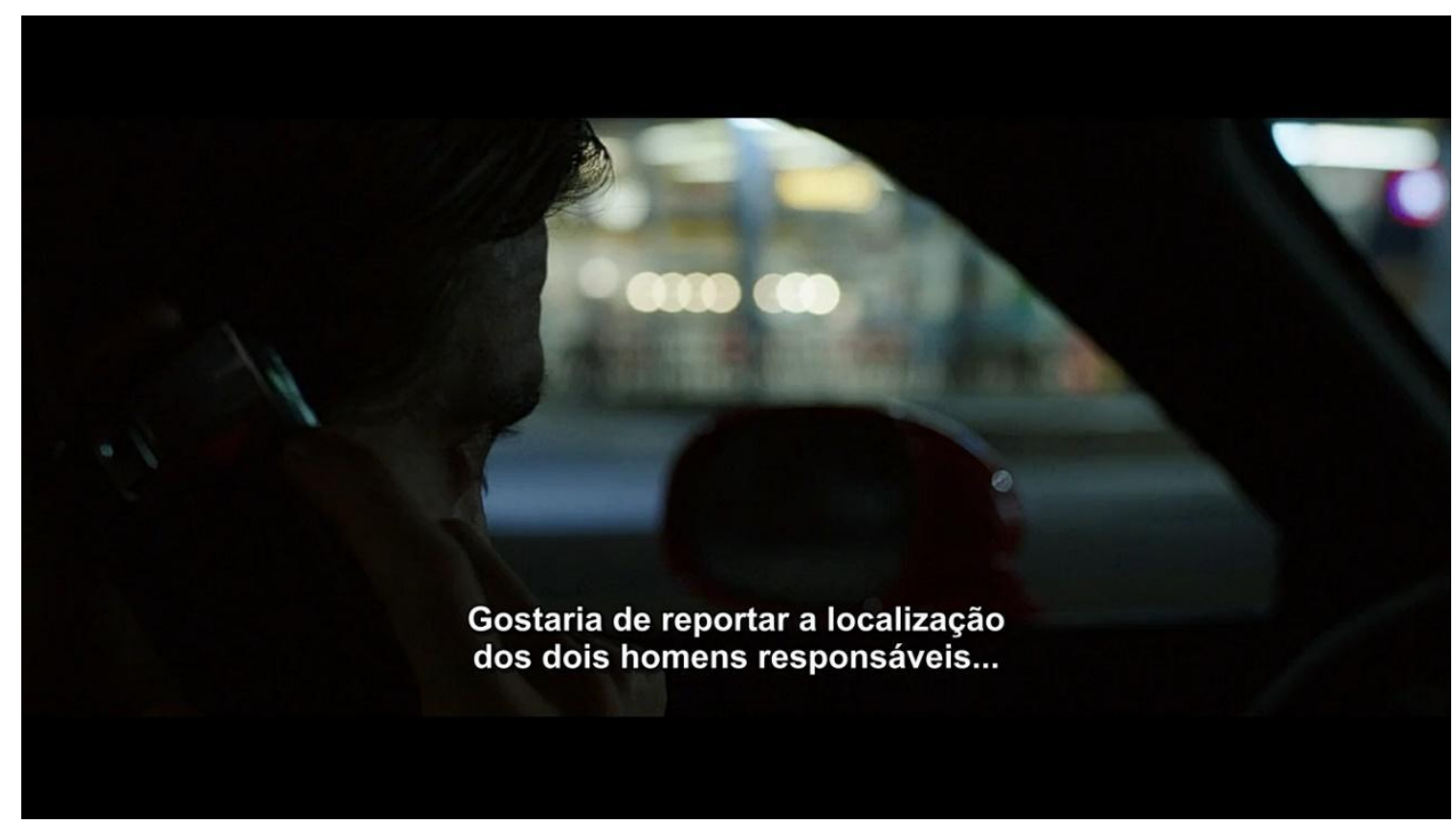

Print Screen do filme O Abutre (2014). Tempo: 1h32m43s

Após a perseguição policial seguida e filmada por Bloom e seu funcionário, ele consegue alcançar seu objetivo. A suíte, isto é, a reportagem que irá mobilizar a memória do assassinato da família, juntamente com a morte dos assassinos em confronto com a polícia, é novamente exibida pela emissora que, mesmo sob ameaças de confisco da polícia, vai ao ar. Bloom prospera com sua empresa. Outro ponto que retorna e "faz vender" é a valorização de um bom trabalho policial, de caça e captura de bandidos. Não se quer ver a morte de uma próspera família no conforto de seu lar, mas o rosto de "homens maus" e a "justiça” sendo feita. A suíte retoma a notícia e culpabiliza e delega as responsabilidades, como se fechasse um ciclo da demanda social. "Àquele desejamos que a morte traga punição absoluta. A nós próprios transição para um mundo melhor" (PEREIRA, 2012, p. 137).

\section{Discurso ficcional: entre cinema e jornalismo}


Neste tópico, consideramos os pontos que tocam as produções ficcionais entre o discurso cinematográfico e o jornalístico. O que permeia esses discursos é sempre-já a possibilidade de formulações metafóricas, ambivalências, jogos de palavras. O cinema edita suas obras, tal como o jornal é montado para vender, para provocar os afetos. Há algo que significa o/no simbólico, aquilo que compartilhamos, por e pela linguagem, na inscrição de outros dizeres atualizados as condições sócio-históricas. Pêcheux (2015) estabelece que,

[...] o interdiscurso, longe de ser efeito integrador da discursividade torna-se desde então seu princípio de funcionamento: é porque os elementos da sequência textual, funcionando em uma formação discursiva dada, podem ser importados (meta-forizados) de uma sequência pertencente a uma outra formação discursiva que as referências discursivas podem se construir e se deslocar historicamente (PÊCHEUX, 2015, p. 158, grifos do autor).

É na medida em que as línguas se articulam e se (re)formulam na e com a dinâmica histórica, que o discurso se implica na articulação polissêmica - "que é o processo de instauração da multiplicidade de sentidos" e parafrástica - "que é o processo pela qual procura-se manter o sentido igual sob diferentes formas" (ORLANDI, 1981, p. 11). Assim, porque há contradição na constituição do sujeito, seu lugar social e no próprio processo histórico, que há possibilidade de efeitos polissêmicos na formulação discursiva. É por meio dessa contradição que entendemos a produção da imagem cinematográfica, bem como a da notícia a ser circulada, como um "trabalho de tensão entre a imagem visual e a sonora" (SOUZA, 2015, p. 63).

É a partir do exposto que se baseiam as análises dos recortes abaixo, na linha de que esses discursos (cinematográfico e jornalístico) estão atravessados pela montagem, estabelecida aqui como "a seleção de planos e cenas que esculpem tanto o tempo como o espaço, instituindo um pensamento que expressa esteticamente uma reflexão sobre o sentido (ou mesmo o não sentido) da existência do homem em sua passagem pelo mundo" (SOUZA, 2015, p. 6o). 


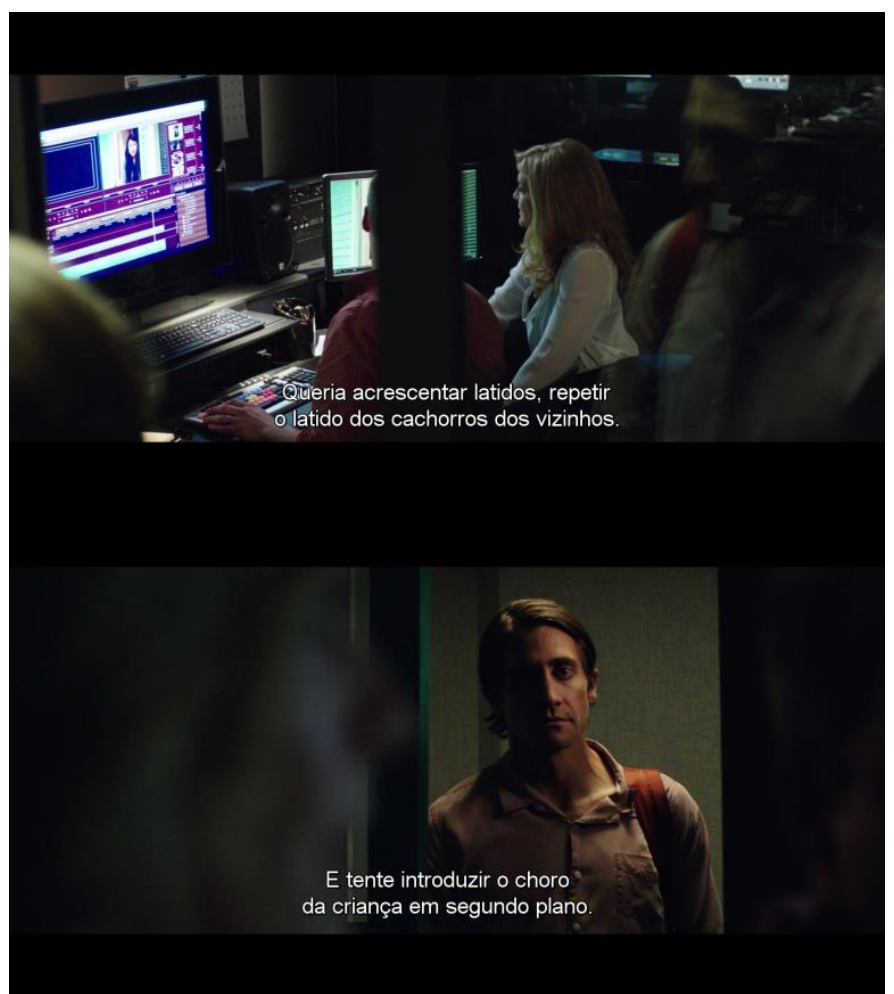

Print Screen do filme O Abutre (2014). Tempo: 17m26s; 17m28s, respectivamente

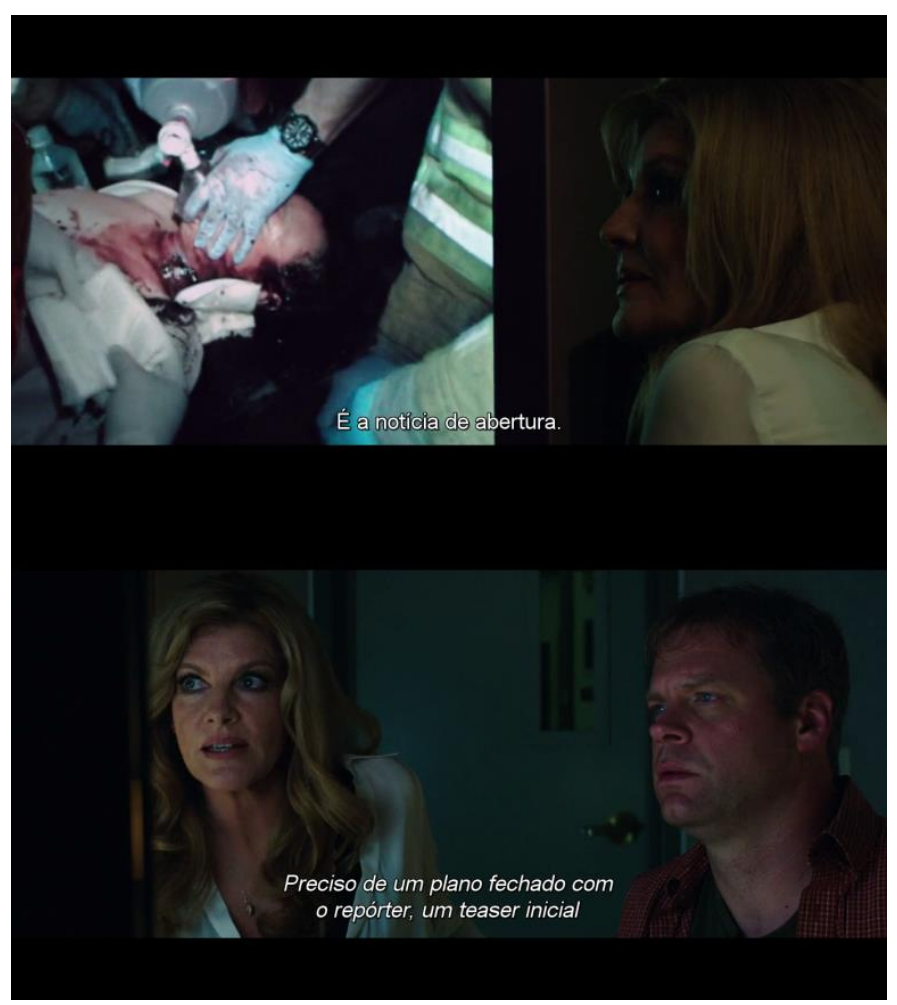

Revista Investigações, Recife, v. 32, n. 2, p. 396 - 418, Dezembro/2019 


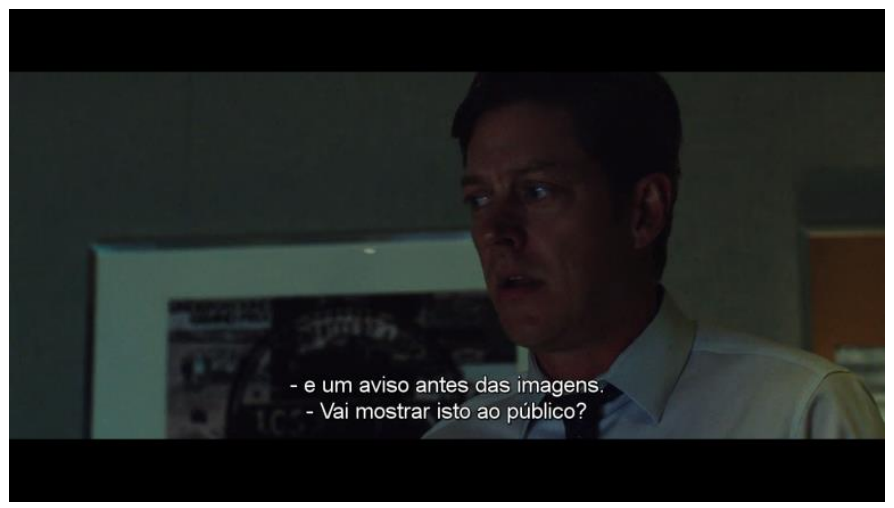

Print Screen do filme O Abutre (2014). Tempo: 19mo8s; 19m1os; 19m13s e 19m15s, respectivamente

A obra cinematográfica em questão é quase sempre a meia luz, como se estivéssemos à espreita, ou na redação de um jornal, selecionando imagens para a nova manchete. As luzes nos rostos das personagens funcionam como se telas de computadores ou televisores estivessem ligados e iluminando suas faces. O trabalho é noturno, e o escuro (ou quase escuro) retorna sempre ao trato com a tragédia, o dramático, significando nossa relação ritualística com a morte, as cores pretas do luto. Uma vez que, "ao ser bem dita, bem simbolizada, bem ritualizada, a morte não faz senão evidenciar a vida” (PEREIRA, 2012, p. 121).

No primeiro recorte, Louis Bloom aparece sem ser esperado, não pediram para que ele ali estivesse, mas ele observa e antes que ofereça seu material imagético, Nina está falando sobre a edição de outra notícia. Sua fala aponta para uma dinâmica em um processo anterior à circulação da notícia. Ela precisa ter um efeito no espectador, algo que pareça a eles familiar, traços comuns do cotidiano de um bairro para pais, filhos e seus animais de estimação. Mas é preciso marcar com o caos; o choro da criança indica sofrimento, algo não se passa tão bem por ali. A sonoridade que é imposta, na edição de Nina, é que vai ditar o ritmo e o como os sentidos (e não-sentidos) serão controlados, ainda que sempre escapem. Assim, em um deslocamento da montagem cinematográfica para a montagem da notícia, entende-se que,

a defasagem entre o real e a imagem assegura ao diretor a vantagem de criar uma construção através dos planos e das cenas do filme [notícia] de um mundo que o diretor pensa ser o sentido deste real. Por isso, dinamiza pela ficção uma ordem, exibe um real que nunca pode ser apreendido totalmente e que sempre escapa (SOUZA, 2015, p. 61).

O segundo recorte apresenta um jogo de cenas após Louis entregar suas filmagens de um acidente. A "frieza" do material, com uma exposição mais marcada de sangue, 
feridas e corpos trucidados, resulta numa aceitação rápida por parte da produção, ou seja, as imagens serão manchetes do telejornal. Louis parece ter aprendido rápido sobre como vender acontecimentos. O que retorna é a fala da personagem sobre a edição, antes que ela apareça na televisão. É preciso conquistar o espectador, oferecer-lhe um texto que diga antes o que está por vir, ou seja, direcionar seu olhar. É esse também um momento de suspensão do juízo. O aviso, o alerta antes das imagens - que no cinema corresponde ao "baseado em fatos reais" ou mesmo a classificação indicativa do filme -, o enquadramento, os cortes, o que vai ser colocado em cena, que provoca perguntas como "vai mostrar isso ao público?", são os pontos que convergem ao discurso cinematográfico e jornalístico, o deslize constitutivo da linguagem. O traço ideológico imbricado ao funcionamento desses discursos ficcionais que circulam e reformulam "o ponto de encontro de uma atualidade e uma memória" (PÊCHEUX, 2015, p.17). O ponto de cisão é que o discurso jornalístico circula com o efeito de objetividade e imparcialidade e o cinema estaria liberado para "florear". É o efeito de evidência deste ponto de cisão que o filme põe sob suspeita.

\section{Considerações finais}

Com efeito, O Abutre funciona como um discurso cinematográfico sobre os bastidores de programas sensacionalistas da televisão californiana. O labor da produção jornalística alimentada com informações e imagens vendidas por freelancers (trabalhadores precarizados) à espreita de acontecimentos capazes de produzir notíciassensação. Tais notícias se inscrevem em uma memória, e esta resvala no "apagamento" e na atualização de dizeres e imagens sempre outros. $\mathrm{O}$ enquadramento, os cortes e a montagem das matérias noticiadas direcionam os sentidos, o olhar e potencializam um efeito de transparência e de uma "mono-verdade" aos fatos, sob a máxima da (im)parcialidade do jornal. A memória discursiva, que vem à tona no tracejar das imagens, permite a reprodução de um determinado imaginário social.

Ainda que registre fatos, a seleção, edição e montagem do factual, tornado notícia veiculada, o ficcionaliza. É necessário que os fatos correspondam ao script conforme dadas coordenadas do imaginário social. Segundo o script sugerido no filme, noticiam- 
se, sobretudo perturbações da ordem social, em que vítimas, protagonistas e antagonistas podem/devem realizar papéis mais ou menos preestabelecidos. Acontecimentos que não seguem essas coordenadas ou não se tornam notícia, ou são editados para melhor obedecer ao script. Desse modo, um filme de ficção, O Abutre, nos apresenta algo de verdadeiro sobre os bastidores do discurso jornalístico sensacionalista, supostamente factual, de modo que o limiar entre ficção e realidade é borrado. Quem consome essa realidade ficcionada? O telespectador ávido de sensações?

A disseminação da imprensa nas sociedades modernas, especialmente em regimes políticos democráticos liberais, parece ter como leitmotiv tornar a sociedade mais transparente a si mesma, desde que respeitados certos limiares entre a esfera pública e a esfera privada. Manter os cidadãos devidamente informados acerca dos acontecimentos pertinentes sobre o comum a todos seria a razão de ser do ofício de profissionais do jornalismo. Por outro lado, para além deste ideal de transparência, o valor-notícia não está fora do ideológico, como o entendemos em Análise de Discurso, uma vez que o crivo valorativo do fato noticiável exige interpretação frente a um mundo de significações históricas. Contudo, o valor-notícia, sobretudo o valor notícia-sensação (que encontramos em nossas análises), responde não apenas a uma necessidade de informação, mas parece pautar-se, antes de tudo, por uma demanda (de mercado) de sensações de leitores/espectadores/consumidores. O valor notícia-sensação subsume-se à lógica do valor troca. No limite, tal lógica impera tanto pela superação de eventuais escrúpulos éticos, quanto pelo atropelamento da ideal necessidade de informação ou de transparência do comum. Esse deslimite é ilustrado no hiperbólico conto Homem Morde Cachorro, de Donald Honig, e no discurso cinematográfico de O Abutre.

\section{Referências}

ACHARD, Pierre. Memória e produção discursiva do sentido. In: ACHARD, Pierre et al. Tradução: José Horta Nunes. 4aㅡ Ed. Campinas, SP: Pontes Editores, 2015.

ALTHUSSER, Louis. Aparelhos Ideológicos de Estado. $3^{\mathrm{a}}$ Ed. Rio de Janeiro: Edições Graal, 1987. 
ALTHUSSER, Louis. Sobre a Reprodução. [1995] Tradução de Guilherme João de Freitas Teixeira. Introdução de Jacques Bidet. 2 ed. Petrópolis: Vozes, 2008.

BECK, Maurício. O Discurso do Cinema-documentário Carioca: a prática fotográfica e os modos de significar o espaço urbano. Anais do II Seminário Interno de Pesquisas do Laboratório Arquivos do Sujeito, UFF, Niterói, 2, p. 106-113, 2013.

BEY, Hakim. Caos: terrorismo poético e outros crimes exemplares. Tradução de Patricia Decia \& Renato Resende. São Paulo: Conrad, 2003.

DUNKER, C. I. L.; RODRIGUES, A. L. SENHORINI, H. Afetos em cena. São Paulo: nVersos, 2017.

HONIG, Donald. Homem morde Cachorro (1960). In: HITCHCOCK, Alfred. (org.) Histórias Macabras. Rio de Janeiro: Record, 1979.

MARIANI, Bethania. O PCB e a imprensa: os comunistas no imaginário dos jornais (19221989). Rio de Janeiro: Revan; Campinas: Editora da Unicamp, 1998.

PENA, Felipe. Teoria do Jornalismo. 2.ed. São Paulo: Contexto, 2008.

PÊCHEUX, Michel. Semântica e discurso: Uma crítica à afirmação do óbvio. 5.ed. Campinas: Ed.Unicamp. 2014.

Papel da memória. In: ACHARD, Pierre et al. Tradução: José Horta Nunes. $4^{\underline{a}}$ Ed. Campinas, SP: Pontes Editores, 2015.

. O Discurso: estrutura ou acontecimento. Tradução: Eni P. Orlandi - $7^{\text {a }}$ Edição, Campinas, SP: Pontes Editores, 2015.

Metáfora e Interdiscurso. In: ORLANDI, Eni Puccinelli (Org.). Análise de Discurso: Michel Pêcheux. - 4ª ed. - Campinas, SP: Pontes Editores, 2015.

PEREIRA, Clóvis. Thânatos e civilização: a morte, entre a psicanálise e a história cultural. - São Paulo: Annablume, 2012.

ORLANDI. Eni Puccinelli. Segmentar ou recortar?. In: V Encontro Nacional de Linguística, PUC, Rio de Janeiro, 1981. p. 9-26.

SOUZA, Enéas de. Da montagem nascem os verdadeiros filmes. In: DUNKER, Chistian Ingo Lenz; RODRIGUES, Ana Lucilia (Org.). A realidade e o real: verdade em estrutura de ficção. $2^{\mathrm{a}}$ Ed. São Paulo: nVersos, 2015.

TRAQUINA, Nelson. Teorias do Jornalismo, Volume II: A tribo jornalística - uma comunidade interpretativa transnacional, 2. ed. Florianópolis: Insular, 2008. 
* Mestre no Programa de Pós-Graduação em Letras: Linguagens e Representações, pela Universidade Estadual de Santa Cruz (UESC).

** Mestra em Letras: Linguagens e Representações, pela Universidade Estadual de Santa Cruz (UESC).

*** Professor e pesquisador no Programa de Pós-Graduação em Letras: Linguagens e Representações, da Universidade Estadual de Santa Cruz (UESC). Doutor em Letras (Estudos Linguísticos) pela UFSM. 